\title{
Long-term Biomonitoring of Alpine Waters in the Swiss National Park
}

\author{
Christopher T. Robinson \& Beat Oertli
}

Keywords: glacier, Swiss Alps, streams, ponds and lakes, Coleoptera, Trichoptera, Chironomidae, Ephemeroptera

\section{Abstract}

This paper summarizes the initial results from the long-term monitoring program of running and standing waters in a high elevation cirque landscape (Macun Lakes) in the Swiss National Park. The region comprises two contrasting basins with different water sources, a glacier-fed basin and a precipitation-fed basin. Monitoring encompasses annual measures of physico-chemistry of the waters along with samples of macroinvertebrates in midsummer. Monitoring was initiated in 2001 when the area was annexed to the park. Preliminary results indicate the high sensitivity of alpine waters and biota to changes in climate. Results from the stream measures suggest a shift in physico-chemistry (warmer waters, decreases in nitrogen constituents) and zoobenthos (taxa and density decreases) over time that reflected the differences and changes in water source in each basin. Results from the pond monitoring showed the rapid response of these small water bodies to alterations in air temperature and pluviometry. The pond data also demonstrated a strong spatial heterogeneity between ponds in both physico-chemistry and macroinvertebrate composition. The monitoring of both streams and ponds provides a holistic picture of abiotic and biotic changes of alpine waters to landscape and climate change.
Profile

Protected area

Swiss National Park

Mountain range

Alps

Country

Switzerland

\section{Introduction}

Lentic and lotic water bodies are prominent features of alpine landscapes, often comprising interconnected hydrologic pathways. Most alpine waters originate during glacial recession, e.g. cirque and kettle lakes and ponds, and many have inlet and outlet streams forming lake chains along drainage pathways (Donath \& Robinson 2001; Maiolini et al. 2006; Robinson \& Matthaei 2007). The juxtaposition of streams and ponds/ lakes enhances overall habitat heterogeneity and potentially aquatic biodiversity (Monaghan et al. 2005; Brown et al. 2006; Maiolini et al. 2006), but can also potentially fragment populations from upstream areas (Monaghan et al. 2002; 2005). Moreover, the insular nature of alpine regions constrains the distribution of species colonizing and inhabiting alpine streams and lakes (Hieber et al. 2005) and the relatively harsh environmental conditions further limit the kinds and numbers of invertebrates found in alpine freshwaters (Lods-Crozet et al. 2001; Ilg \& Castella 2006). Alpine landscapes in general are recognized as sensitive environments to climate change (Körner 1999) and freshwater biota are probably excellent sentinels for detecting and documenting such changes. The generally low taxon richness of alpine freshwaters suggests habitats are not species saturated (Hinden et al. 2005; Oertli et al. 2008; Rosset et al. 2008) and as such are susceptible to invasive species or species expanding their ranges as alpine environments become more suitable for colo-

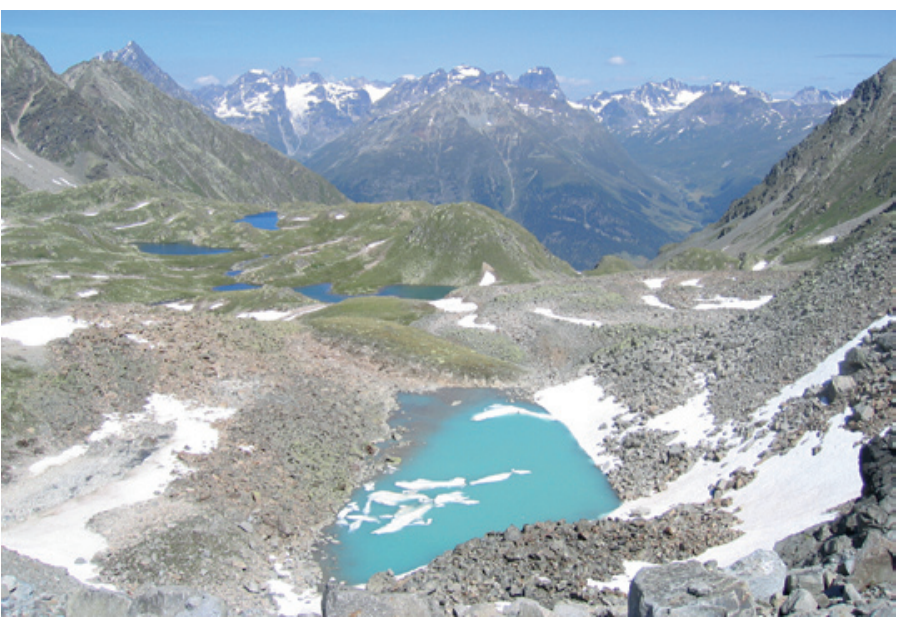

The ponds within the Swiss National Park. (C) bepia

nization. Consequently it is important to document species presence in the face of rapid environmental changes being imposed on alpine landscapes.

The objective of this paper is to summarize the spatio-temporal changes in physico-chemistry and zoobenthos in ponds/lakes and streams of a high-alpine catchment in the Swiss National Park. The $3.6 \mathrm{~km}^{2}$ Macun region was annexed to the Swiss National Park in 2000 and currently is an area designated for longterm monitoring of alpine streams and lakes. A secondary objective is to relate the zoobenthic data with any changes in associated physical and chemical measures collected on the same dates over the 8 year period of study. 


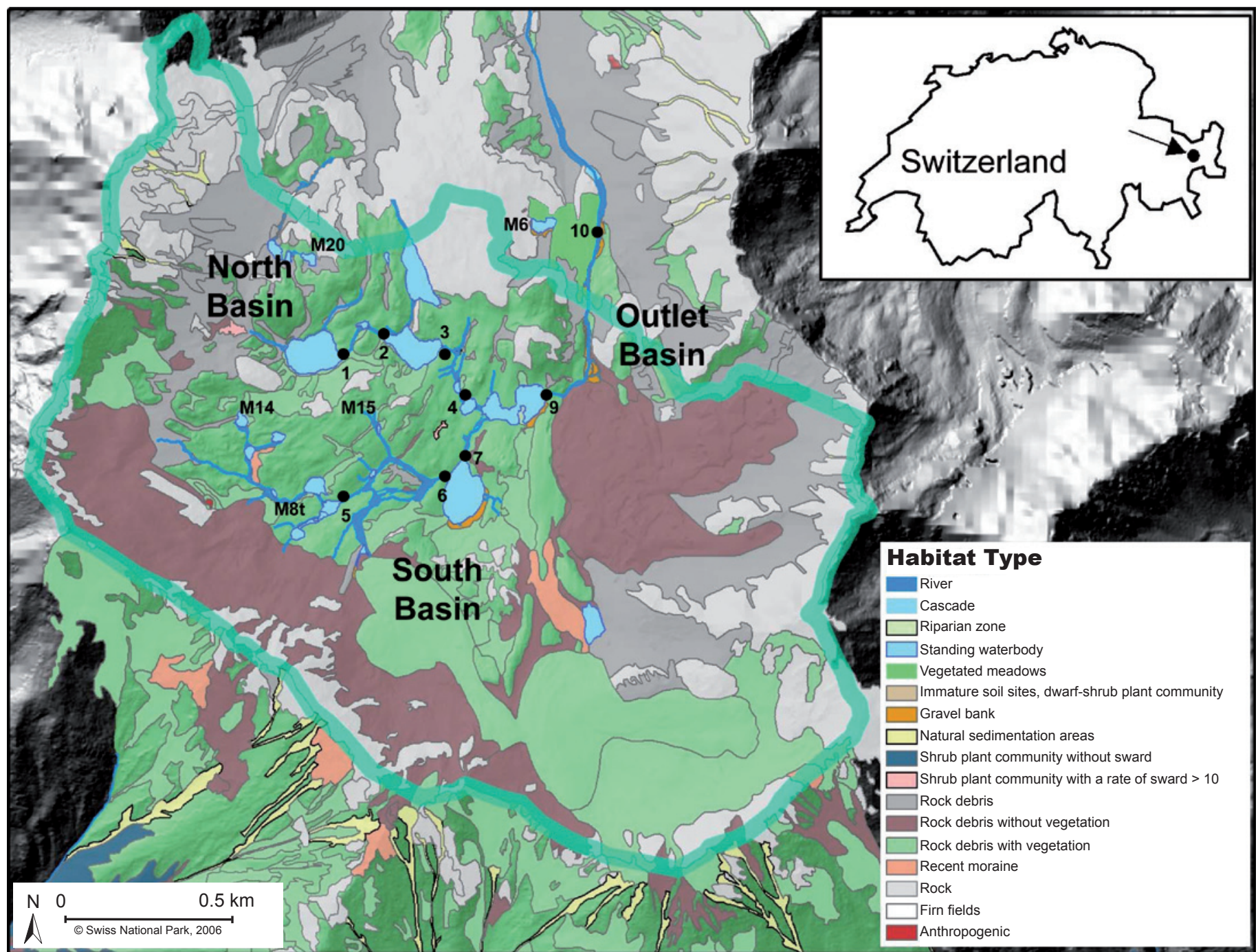

Figure 1 - Map of the Macun Lakes region with numbers indicating sample locations on streams and ponds. Map adapted from Robinson and Matthaei (2007), and Oertli et al. (2008).

\section{Study Area}

The Macun catchment $\left(46^{\circ} 44^{\prime} \mathrm{N}, 10^{\circ} 08^{\prime} \mathrm{E}\right)$ is a highalpine cirque $(>2600 \mathrm{~m})$ in the Canton Graubünden, Switzerland (Figure 1). The surrounding peaks reach elevations between 2800 and $3000 \mathrm{~m}$, and the outlet stream (Zeznina) drains north to the river Inn near the village of Lavin, Switzerland, in the lower Engadine. Some cattle grazing occurred before the park annex in 2000 , but now the area is visited only by tourists on designated trails.

The region comprises 5 small lakes and 21 permanent ponds (and $\sim 10$ small temporary ponds) scattered within two sub-basins; their surface area ranges between 0.01 and $0.12 \mathrm{~km}^{2}$, with a depth from a few centimetres to about $10 \mathrm{~m}$. The five small lakes, each $\sim 0.12 \mathrm{~km}^{2}$ and $<10 \mathrm{~m}$ deep, are interconnected by streams each around $500 \mathrm{~m}$ in length. A north basin is fed mostly by snowmelt and groundwater, whereas the south basin is fed by glacial melt from a number of rock glaciers. The annual flow regime differs between basins, with the south basin experiencing more extreme channel contraction from the freezing of gla- cial water in autumn. The stream network as a whole contracts by up to $60 \%$ in winter (Robinson \& Matthaei 2007). The water source in each basin also causes differences in water chemistry and water temperature, being warmer in the north basin. There are no active surface (erosional) glaciers in the catchment.

The elevation at the uppermost north basin site was $2631 \mathrm{~m}$ and at the uppermost south basin site $2650 \mathrm{~m}$. The lowermost outlet stream was at $2616 \mathrm{~m}$. Precipitation is low, typically being around $\sim 850 \mathrm{~mm}$ per year. Air temperatures range from over $20^{\circ} \mathrm{C}$ in summer to below $-25^{\circ} \mathrm{C}$ in winter, based on records from a nearby climate station (Buffalora) $\sim 14 \mathrm{~km}$ southeast of Macun. Bedrock geology is slow-weathering crystalline (ortho-gneiss) rock. The area is above the tree line, and most terrestrial vegetation is typical alpine grasses and low lying herbs. Areas of bare rock are common. 

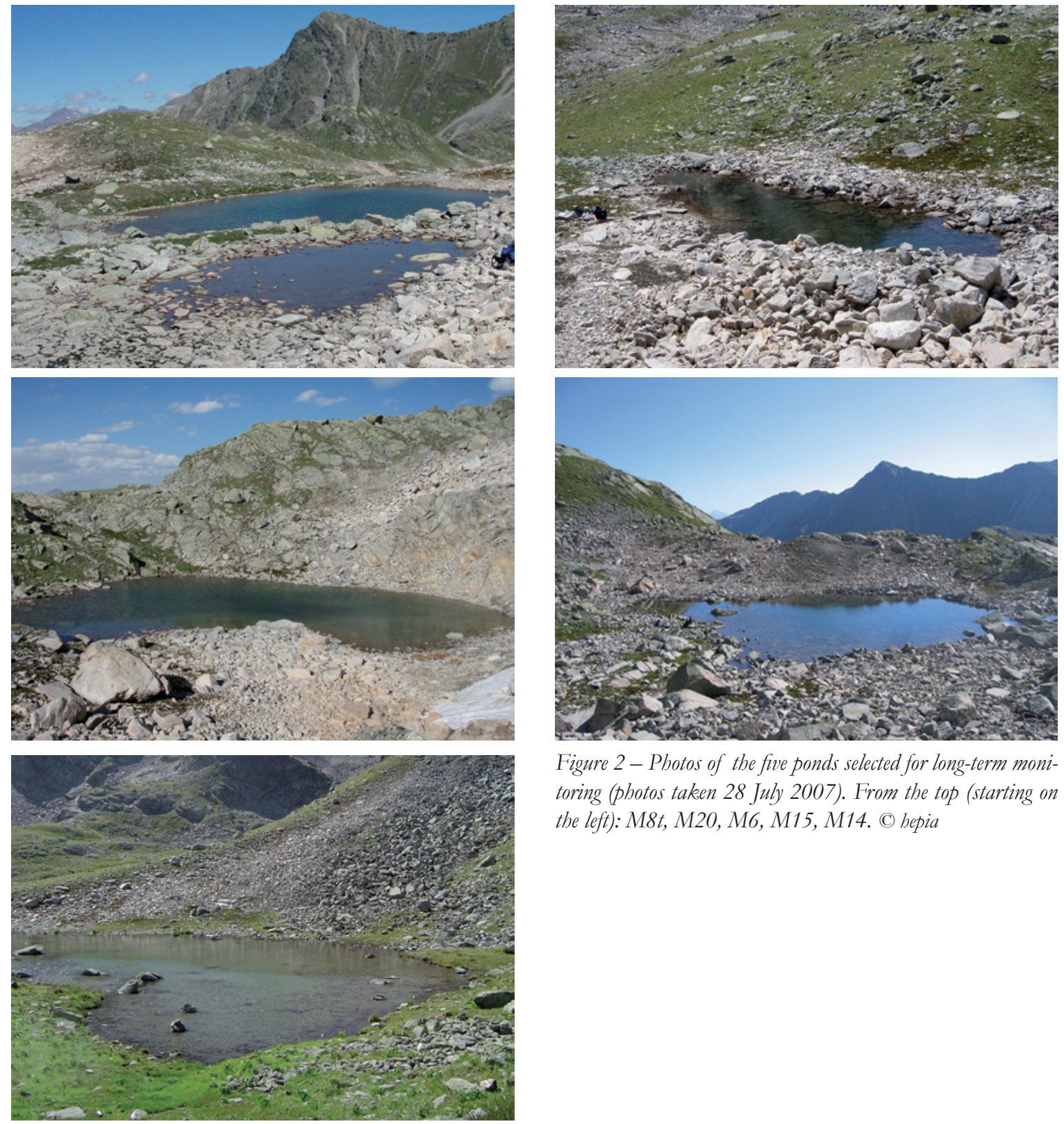

Figure 2 - Photos of the five ponds selected for long-term monitoring (photos taken 28 July 2007). From the top (starting on the left): M8t, M20, M6, M15, M14. (C) bepia

\section{Methods}

\section{Streams}

The biomonitoring of streams was initiated in September 2001, followed by collections in late July or early August from 2002 to 2008. For streams, nine sites were sampled on each date: four in the north basin, three in the south basin, and two in the outlet stream (Figure 1). The sites were situated at the inlets and outlets of the prominent lakes in each basin along a longitudinal gradient. Lake Immez is located at the confluence of the north and south drainage channels, and stream site 9 was at its outlet stream. Meltwater from a large rock glacier enters the outlet stream between stream sites 9 and 10 .

A 1-L water sample was collected from each site on each visit for analysis of nitrate- $\mathrm{N}$, particulate $\mathrm{N}(\mathrm{PN})$, particulate $\mathrm{P}(\mathrm{PP})$, dissolved organic matter (DOC), and particulate organic matter (POC) following me-

thods in Robinson and Matthaei (2007). On each visit spot measures were taken around midday for temperature, conductivity, turbidity and $\mathrm{pH}$, using fieldportable meters. Spot measures were used to provide information on basin and site differences in measured parameters. A detailed analysis of the seasonal variation in physico-chemistry and hydrology of the catchment is found in Robinson and Matthaei (2007).

Benthic invertebrates were sampled semi-quantitatively using a timed (5 min) kick-net approach. Along a $30 \mathrm{~m}$ reach at each site, benthic substrata were disturbed and the loosened material collected in the net $(250 \mu \mathrm{m}$ mesh). Primary habitat types (e.g. pools, runs, riffles) were sampled proportionately during the 5 min sample. The material collected was preserved with $70 \%$ ethanol for later processing in the laboratory. In the laboratory all invertebrates were handpicked from each sample, identified to lowest possible taxonomic unit and counted. Chironomidae collected in the 2002 

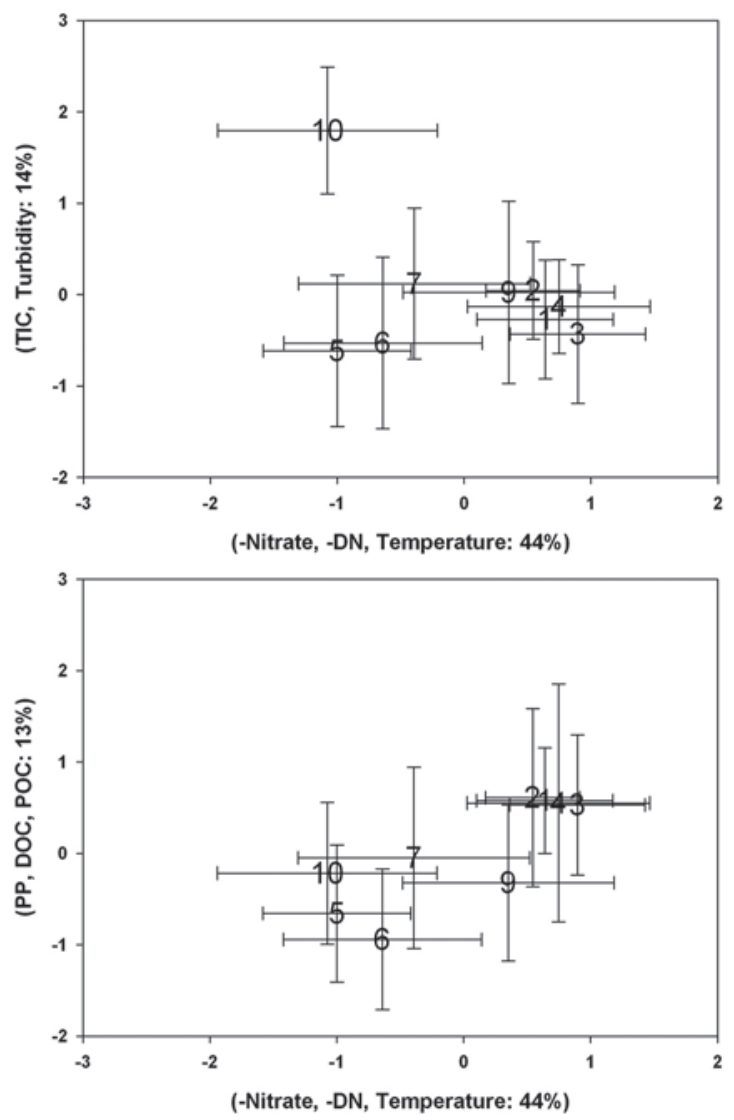

Figure 3 - Scatter plot of principal components analysis of water physico-chemistry attributes from the nine long-term monitoring sites used for stream assessment. Figure 3 a (top panel) plots factor 1 against factor 2 and Figure $3 b$ (bottom panel) plots factor 1 against factor 3. Error bars are standard deviations based on the annual measures ( $n=8$ for each site). $D N=$ dissolved nitrogen, TIC = total inorganic carbon, $P P=$ particulate phosphorus, $D O C=$ dissolved organic carbon, $P O C=$ particulate organic carbon. $A$ negative sign before a measure indicates a negative relationship of that measure along that axis.

samples were identified to species, except for the genera Limnophyes and Microspectra, based on examination of slide mounts (see Robinson et al. 2007). For this paper, all data were evaluated using descriptive and multivariate statistics for illustrative purposes.

Lakes and ponds

The biomonitoring of lentic water bodies was initiated in summer 2002 (16-22 July), followed by collections in 2004 (27 July to 2 August), 2005 (17-26 July), 2007 (27-28 July) and 2008 (6 August). Collections in 2002 and 2004 from about 30 temporary or permanent ponds and small lakes served to compile a complete inventory and establish a baseline of lentic fauna (see Oertli et al. 2008). The long-term monitoring was built on this base and a selection of five ponds representative of the ponds/lakes were chosen (Figure 2): three ponds (M8t, M15, M20) were sampled every two years and two ponds (M5, M14) every four years, beginning in 2005. A new complete inventory from the 30 ponds is scheduled every twelve years (next in 2014).

The five chosen ponds differed in their macroinverte-
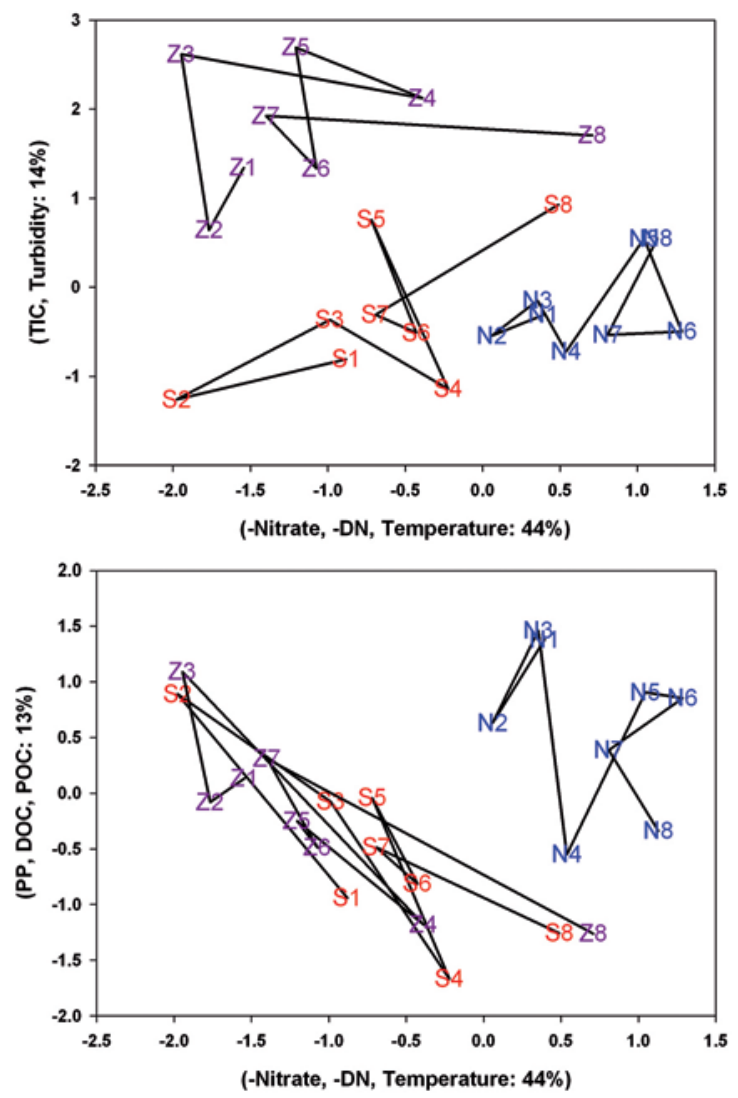

Figure 4 - Scatter plot of principal components analysis used in Figure 3, using average loadings for all years from all sites in the north basin $(n=4)$, all sites in the south basin $(n=3)$, and site $10(Z$ ernina $=Z)$. Lines connect the average scores with a letter indicating basin $(N=$ north basin, $S=$ south basin) and a number indicating the year of sampling (e.g., $N 1=$ north basin 2001, N2 = north basin 2002). Figure 4 a (top panel) plots factor 1 against factor 2 and Figure $4 b$ (bottom panel) plots factor 1 against factor 3. Abbreviations as in Figure 3.

brate assemblages and on the magnitude in water level fluctuation: M6 had a high taxonomic richness, M14 had a low taxonomic richness, M8t was a temporary pond, M15 had a high magnitude in water level fluctuation (at times also drying), and M20 was a permanent pond with low water level fluctuation. Two ponds were located in the north basin and three in the south basin (Figure 1). The ponds also differed with regard to the chemical composition of the water. Conductivity, even if low, was highest in M6. All ponds were probably fishless or with a low fish density (a small fish was observed in M14 in 2004). The physico-chemical characteristics of these ponds are presented in Table 1 .

As for streams, a 1-L water sample was collected from each site on each visit for analysis of different forms of nitrogen, phosphorus and carbon. On each visit spot measures were taken around midday for conductivity and $\mathrm{pH}$ using field-portable meters. In addition, data loggers were placed in a selection of ponds for continuously measuring temperature and water level (measures every hour, from July 2006 and July 2007). Macroinvertebrates were collected from pond M6 in 

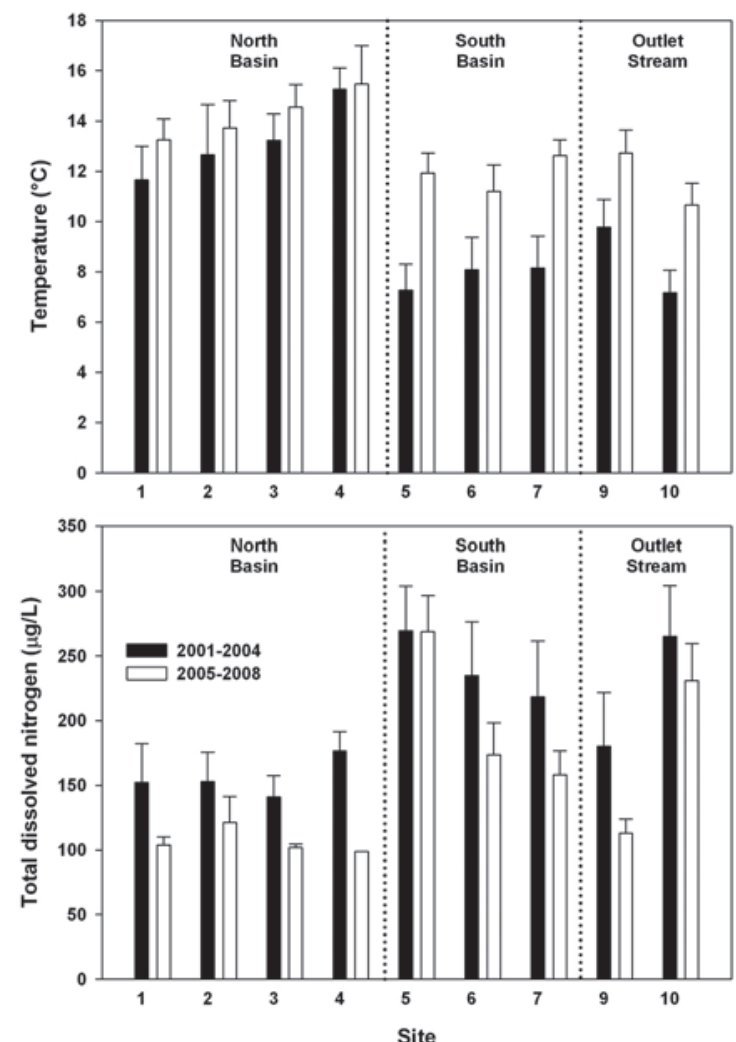

Figure 5 - Average temperature ( $+S E$ ) and total dissolved nitrogen for stream sites in the north basin, south basin and catchment outlet for the periods 2001-2004 (black bars) and 20052008 (white bars). Values based on spot measures recorded at nearly the same date in each year at each site $(n=4$ for each site and period). Sites arranged longitudinally in each basin.

2002 and 2007, from M8t in 2002, 2004, 2005 and 2007, from M14 in 2004 and 2007, and from M15 and M20 in 2004, 2005 and 2007. The standard procedure "PLOCH" (Oertli et al. 2005a; 2008) was used for sampling. Macroinvertebrates were collected with a small-framed hand net (rectangular frame $14 \times 10 \mathrm{~cm}$, mesh size $0.5 \mathrm{~mm}$ ). For each sample the net was swept through the water intensively for 60 seconds. The number of samples taken, depending on pond size, ranged from 2 (smallest pond, M8t) to 13 (largest pond, M6). Sampling was stratified for the dominant habitats (from the land-water interface to a depth of $2 \mathrm{~m}$ ), including stones, gravel, sand and bryophytes. In all cases the collected material was preserved in $70 \%$ ethanol and then comprehensively sorted in the laboratory. Specimens were identified to species level for most taxonomic groups (including Chironomidae and Oligochaeta) and counted. Pupae were generally not considered, although some were identified when species level identification was impossible for larvae.

\section{Results}

Stream physico-chemistry

A principal components analysis (PCA) of the stream sites, based on measured physical and chemical constituents, separated sites by basin (Figure 3). The north basin sites displayed lower values of nitrate- $\mathrm{N}$ and dissolved nitrogen, and higher temperatures than south basin sites. Site 9 below Lake Immez, which has water from both basins, was oriented more towards the north basin sites, but was placed closer to south basin sites than the other south basin sites. Site 10 downstream of site 9, but with a strong influence of the rock glacier, was placed along with south basin sites along axis-1, although showing higher TIC and turbidity values than those sites. Site 10 also displayed similar PP, DOC and POC values as south basin sites, whereas north basin sites had generally higher values for these measures. The similar error bars for all sites suggest similar temporal change over the years of study.

A second PCA illustrated the year-to-year changes for all sites combined in the north basin, in the south basin, and for site 10 (Figure 4). Two patterns became clear. One pattern was that the south basin sites exhibited more change over time than the north basin sites. The second pattern was that both basins showed a major shift over time, with the years 2001-2004 generally grouped together and the years 2005-2008 grouped together. Site 10 was not as clear in this regard, but still shifted among years along axis-1 (Figure 4a, b) and similarly along axis-2 (PP, DOC, POC) as the south basin sites (Figure 4b).

Temporal changes in temperature and dissolved nitrogen were used to illustrate this shift from 2004 to 2005 (Figure 5). Temperature generally increased for all sites for years grouped as 2001-2004 and those grouped 2005-2008, but sites in the south basin showed a much

Table 1 - Description of environmental variables characterizing the five ponds selected for long-term monitoring (measures from 2002 and 2004). The two variables motivating the choice of these five ponds were taxa richness of macroinvertebrates and the magnitude in water level fuctuation. "nd": information not discriminative for the selection of the five ponds.

\begin{tabular}{|c|c|c|c|c|c|}
\hline & M6 & M8t & M14 & M15 & M20 \\
\hline Altitude (m) & 2398 & 2669 & 2663 & 2663 & 2653 \\
\hline Location in the Macun cirque & North & South & South & South & North \\
\hline Mean depth $(\mathrm{m})$ & 0.8 & 0.35 & 1.5 & 1.2 & 3.5 \\
\hline Max depth (m) & 0.5 & 0.15 & 0.9 & 0.5 & 1.8 \\
\hline Conductivity $(\mu \mathrm{S} / \mathrm{cm})$ & 68 & 11 & 4 & 4 & 5 \\
\hline Water level fluctuations & nd & high (temporary pond) & nd & high & low \\
\hline Macroinvertebrate taxa richness & high & nd & low & nd & nd \\
\hline
\end{tabular}



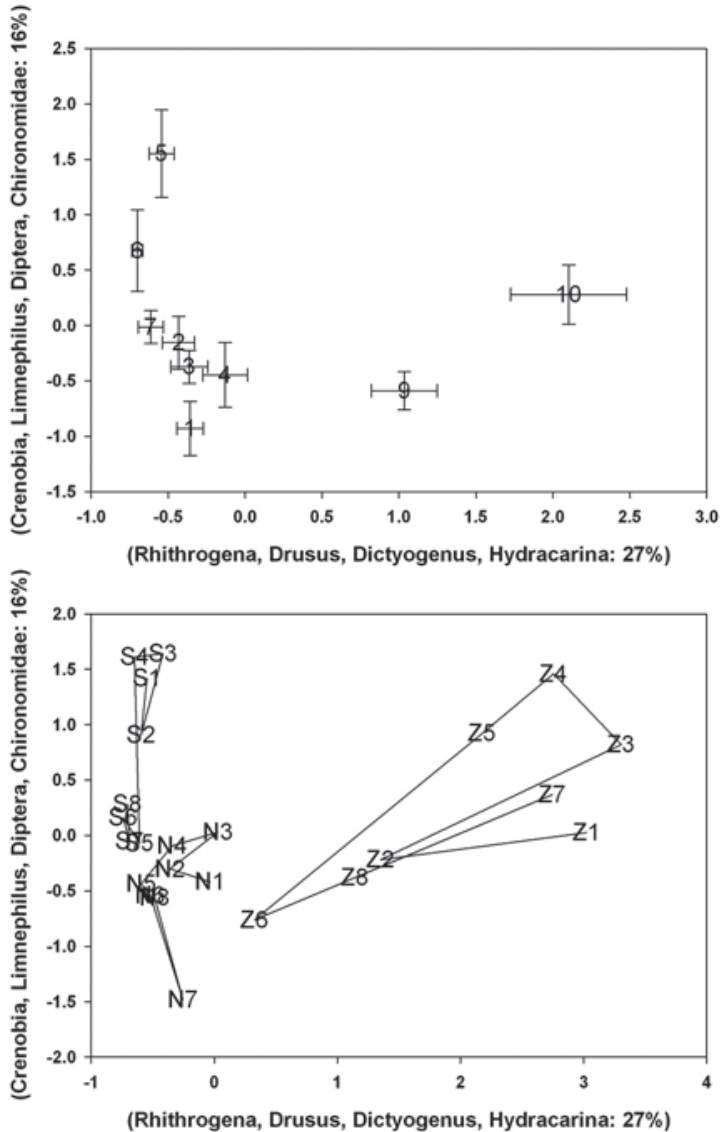

Figure 6 - Scatter plot of principal components analysis based on the density of macroinvertebrate taxa collected from each of the stream sites. Figure 6a (top panel) presents the PCA results with all years combined for each site, where error bars are standard deviations ( $n=8$ for each site). Figure $6 b$ (bottom panel) presents the PCA results as averages for each year for sites combined in the north basin ( $n=4$ sites), south basin ( $n$ $=3$ sites), and site 10 (Zeznina $=Z$ ). Lines connect the average scores with a letter indicating basin $(N=$ north basin, $S=$ south basin) and a number indicating the year of sampling (e.g. N1 = north basin 2001, N2 = north basin 2002).

greater average increase in temperature by up to $4^{\circ} \mathrm{C}$. By contrast, dissolved nitrogen generally decreased between these periods and was more pronounced in the north basin sites and higher order south basin sites. Here, dissolved nitrogen values decreased by up to $50 \mu \mathrm{g} / \mathrm{L}$ in these sites between the two periods. Little change in dissolved nitrogen was observed in site 5 and site 10 , both being directly influenced by inputs from rock glaciers.
Stream zoobenthos

The PCA based on the most common macroinvertebrates (those representing $>1 \%$ of the assemblage in samples) in the streams showed that the composition differed between basins (Figure 6). Crenobia alpina, Limnephilus coenosus, Diptera, and Chironomidae were more common in south basin streams than north basin streams. Further, sites 9 and 10 showed greater abundances of Rhithrogena loyolaea, Drusus destitutus, Dictyogenus sp. and Hydracarina than north or south basin streams. When grouping sites by basin and comparing years, the PCA showed that the years 2001-2004 grouped together and the years 2005-2008 generally grouped together along axis-2 (Figure 6b). In general, both basins showed decreases in the abundances of taxa loaded on axis-2. Site 10 showed much variation between years but no similar grouping of years as the basin sites. The year groupings were compared for taxa richness and invertebrate density for each basin and the outlet sites 9 and 10 (Figure 7). In general, taxa richness decreased from the years 2001-2004 to the years 2005-2008 for all sites, regardless of basin. Some sites showed an average decrease in richness by 4 taxa, whereas most sites lost 1-2 taxa in this year comparison. Macroinvertebrate density also showed a decrease from years 2001-2004 to years 2005-2008 being more evident in the south basin and higher order sites in the north basin. No differences were observed for sites 1 and 2 in the north basin.

\section{Lake and pond physico-chemistry}

The physico-chemical measures made during the first years of monitoring, between 2005 and 2008 (Table 2), supported the main characterization of the ponds from the initial assessment in 2002 and 2004 (Hinden 2004; Stoll 2005). Indeed, M6 had a higher conductivity, 4 to 20 times higher than the other four ponds, with fluctuations between 68 and $84 \mu \mathrm{S} / \mathrm{cm}$. These values are nevertheless much lower than those usually observed in ponds at lower altitude. The values of the four other ponds were extremely low, between 3 and $15 \mu \mathrm{S} / \mathrm{cm}$. M6 was also distinct by its $\mathrm{pH}$, being the only neutral-basic pond, the other four being acidic. TIC also underlined the distinctiveness of M6, with particularly high values. The other chemical parameters measured (DOC, POC, TP, TN) did not separate the five ponds, all showing a similar range in values. Water temperature fluctuations also were monitored

Table 2 - Measures between 2002 and 2008 of environmental variables characterizing the five monitored ponds. Minimal and maximal values observed between 2002 and 2008.

\begin{tabular}{|l|r|r|r|r|r|}
\hline & $M 6$ & $M 8 t$ & $M 14$ & $M 15$ & M20 \\
\hline Conductivity $(\mathrm{MS} / \mathrm{cm})$ & $68-84$ & $6-15$ & $4-4$ & $3-14$ & $3-8$ \\
\hline $\mathrm{pH}$ & $\approx 7.5$ & $\approx 6$ & $\approx 6$ & $\approx 6$ & $\approx 6$ \\
\hline Total nitrogen $(\mathrm{mg} / \mathrm{L})$ & $0.2-0.2$ & $0.4-0.4$ & $0.1-0.2$ & $0.1-0.3$ & $0.2-0.3$ \\
\hline Total phosphorus $(\mathrm{gg} / \mathrm{L})$ & $6-7$ & $2-6$ & $6-12$ & $2-10$ & $2-12$ \\
\hline $\mathrm{DOC}(\mathrm{mg} / \mathrm{L})$ & 1.9 & $0.4-1.1$ & $0.5-2.3$ & $0.7-1.3$ & $0.5-1.6$ \\
\hline $\mathrm{TIC}(\mathrm{mg} / \mathrm{L})$ & $5.0-6.6$ & $0.0-1.1$ & $0.0-0.0$ & $1.0-1.0$ & $0.0-0.8$ \\
\hline $\mathrm{POC}(\mathrm{mg} / \mathrm{L})$ & 0.41 & $0.17-0.19$ & $0.17-0.40$ & $0.14-0.42$ & $0.22-0.93$ \\
\hline
\end{tabular}



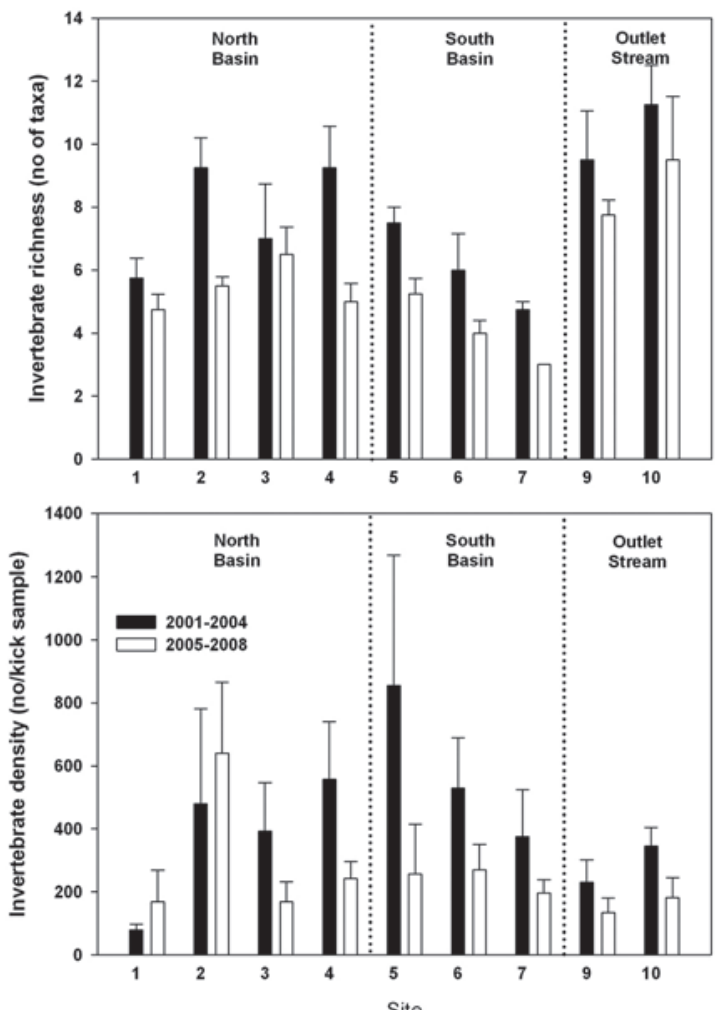

Figure 7 - Average macroinvertebrate taxa richness (+SE) and density (no./ kick sample) for stream sites in the north basin, south basin, and catchment outlet for the periods 2001 2004 and 2005-2008. Values based on 5 minute kick samples taken at nearly the same date in each year at each site (n $=4$ for each site and period). Sites arranged longitudinally in each basin.

(see Lecomte 2008). A representative example of a permanent pond is presented in Figure 8. It shows the long freezing period of the water for about eight months, here between November 2006 and June 2007. This pattern also shows the rapid response in water temperature to meteorological events (and associated changes in air temperature) within a few days, e.g. in summer 2007 (July) the temperature fell from $15^{\circ} \mathrm{C}$ to $3^{\circ} \mathrm{C}$ but also rapidly increased again to $15^{\circ} \mathrm{C}$. Ponds are small water bodies and, as a consequence, have a low thermal resilience to air temperature changes. Therefore nyctemeral changes of temperature are also high with amplitudes sometimes of $5^{\circ} \mathrm{C}$.

Water levels were also monitored (Lecomte 2008). A representative example of the permanent pond M15 between 2006 and 2007 is presented in Figure 8. This pond was selected for monitoring because of its large water level fluctuations. The survey confirmed the fluctuation in its water level and showed a difference of $40 \mathrm{~cm}$ between the maximum (July 2007) and the minimum level (August 2007). It also showed that the pond has a low water level at the beginning of the ice period (November) and a high water level from ice (and snow) melt (June the following year). Monitoring of the water level of the temporary ponds (Figure 9) allowed the precise identification of the duration of dry periods. For M8t two dry periods were observed during summer 2007 and both had short duration (1-3 days). The dry periods are directly related to meteorological conditions: warm temperatures and low pluviometry. The dry period of M8t corresponded also with the low water level of M15.

Lake and pond macroinvertebrates

The taxa richness of the five monitored ponds was heterogeneous (Figure 10). As in 2002, with eleven taxa, pond M20 was richer than the other ponds. M6 was the next richest with nearly ten taxa, and ponds M15 and M8t were species poor with six taxa. The standard deviation was relatively low and showed that there was a low temporal variation in taxa richness during the study period.

The composition of macroinvertebrate assemblages sampled between 2002 and 2007 in the five monitored ponds demonstrated a strong spatial heterogeneity between the ponds (Table 3, Figure 11). Nevertheless, ponds M14 and M15 had relatively similar communities as noted in the PCA (Figure 11). This PCA also shows the main characteristics of the assemblages of the five ponds that are also clear in the abundance data in Table 3. Temporary pond M8t was characterized by the presence of the midge Diamesa zernyi gr. (Diamesinae) and Oligochaete Fridericia ssp. (absent in the other four ponds), and by the absence or paucity of three taxa present in high abundance in the other four ponds: the Oligochaete Cognettia cf. glandulosa, the beetle Agabus bipustulatus and the caddisfly family Limnephilidae. Pond M6 was characterized by high abundances of the bivalve Pisidium casertanum and midge Paratanytarsus austriacus (Chironominae), taxa absent or rare in the other four ponds. Pond M20 was characterized by two species unique to this water body: the beetle Hydroporus memnonius and water boatmen Arctocorisa carinata carinata. Pond M15 was characterized by the absence of the beetle Agabus bipustulatus. Finally M14 was characterized by the paucity of the larvae of the beetle Hydroporus spp.

Some taxa were much more broadly distributed than others. For example, the beetle Hydroporus foveolatus and the caddis fly family Limnephilidae were present in all surveyed ponds, although both were less abundant in the temporary pond M8t. On the other hand, some taxa seem restricted to some ponds. For example, the bivalve Pisidium casertanum was observed only in M6 and in high abundance. The temporal heterogeneity within the ponds was low with relatively low differences in composition between years. This is illustrated in the PCA that shows, in general, a grouping of the same ponds regardless of the sample year (Figure 11). However, it must be noted that some taxa can have a large variation in abundance between years (Table 3 ). 

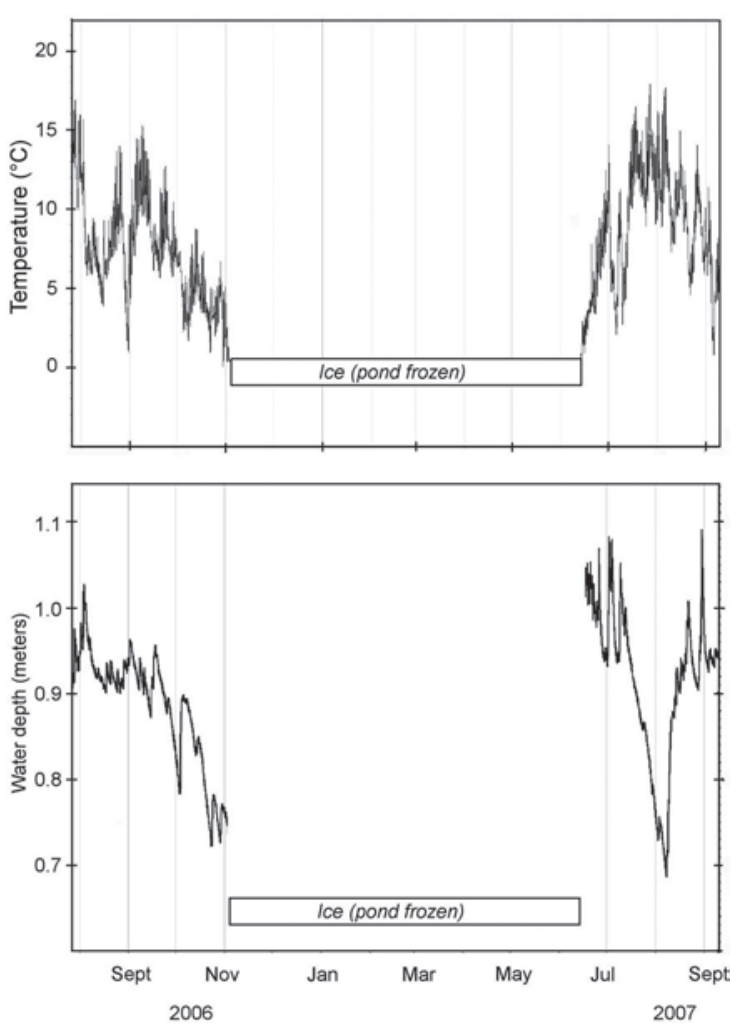

Figure 8 - Water temperature (top) and water level fuctuation (bottom) in pond M15 measured between 26 July 2006 and 10 September 2007. Temperature was measured every hour at a water depth of $10 \mathrm{~cm}$. The empty space between November 2006 and June 2007 represents the period when the water was frozen. A minimum depth was observed at the beginning of August $2007(0.7 \mathrm{~m})$ and a maximum $(1.1 \mathrm{~m})$ was observed some days later at the end of August.

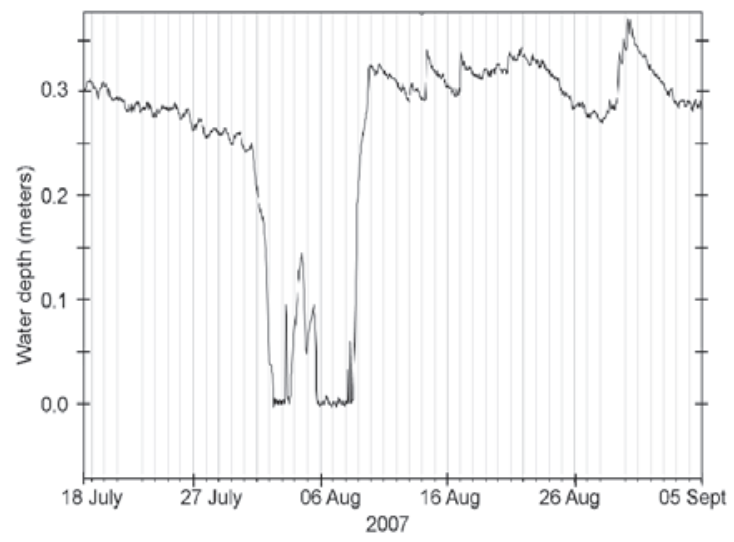

Figure 9 - Water level fuctuations in the temporary pond M8t during summer 2007 (see Lecomte 2008). Two short dry periods are shown here during one day (2-3 August) and three days (6-9 August).

\section{Discussion}

Streams

Although covering a relatively short period, the results from the stream physico-chemistry suggest a temporal shift in water chemistry and temperature. Water temperature has increased rather dramatically and especially in the glacier-fed south basin where temperatures have increased by some $4^{\circ} \mathrm{C}$. The change may reflect a reduction in glacier meltwater from the rock glaciers as no surface glaciers are found in the Macun catchment. The source of water to streams in the south basin now may be proportionately more from precipitation (snow and rain) than glacier melt. In contrast, temperatures in streams of the north basin have increased on average by ca. $2^{\circ} \mathrm{C}$, but are still non-significantly different than the earlier time period. Here the source of water is via precipitation as snow and rain and the slight increase may simply reflect warmer summer temperatures overall. One pattern evident in the north basin streams is the general increase in temperature along the longitudinal dimension, increasing by at least $2-3^{\circ} \mathrm{C}$ from headwaters to the outlet.

Nitrogen constituents have decreased dramatically in the catchment, especially in the more downstream reaches. For instance, total dissolved nitrogen has decreased by as much as $50 \mu \mathrm{g} / \mathrm{L}$ in some streams and was especially pronounced in the north basin streams. Nitrogen is delivered primarily via atmospheric deposition (Malard et al. 2000) and these results may indicate a reduction in nitrogen deposition in the catchment. Likewise the lesser response of streams in the south basin probably reflects the input of glacier meltwater that may strongly influence stream water chemistry. This pattern is evident when comparing site 9 with site 10 , where site 10 is strongly influenced by the meltwater from the large rock glacier in the catchment and shows little reduction in dissolved nitrogen compared to site 9. Recall that site 9 is the outlet stream of the catchment upstream of the rock glacier input and integrates waters from the south and north basin.

The invertebrate data reflected the basin differences in physico-chemistry, with sites 9 and 10 showing more changes in composition from the other sites. Robinson et al. (2007) suggested that site 9 and 10 were more lotic in character than the other sites because of the proximity of the other sites to lake inlets and outlets. The invertebrate data also showed changes in composition over time as was observed in water physicochemistry. These composition changes were reflected in decreases in taxa richness of ca. two taxa at each site and decreases in invertebrate density by almost half at most sites. In fact only the two uppermost sites in the north basin showed no loss but an actual increase in density, whereas all other sites showed substantial decreases in density. These data must be taken cautiously as they are based on only one sample collected at one point in time and may simply be a life history response by different taxa to the changes in temperature (Van- 
Table 3 - Abundances of the main macroinvertebrate taxa characterizing the five monitored ponds between 2002 and 2007. For a full taxa list (also of other ponds from Macun) see Indermueble and Oertli (2007) and Oertli et al. (2008). "- "not sampled, "Code”: code used in Figure 11.

\begin{tabular}{|c|c|c|c|c|c|c|c|c|c|c|c|c|c|c|c|c|}
\hline & & & M6 & & M8t & & & & M14 & & M15 & & & M20 & & \\
\hline & code & & 2002 & 2007 & 2002 & 2004 & 2005 & 2007 & 2004 & 2007 & 2004 & 2005 & 2007 & 2004 & 2005 & 2007 \\
\hline \multicolumn{17}{|l|}{ Oligochaeta } \\
\hline \multirow[t]{2}{*}{ Lumbriculidae } & lumbr & Stylodrilus heringianus & - & 29 & - & & & & & & & & & 1 & 3 & 6 \\
\hline & & Lumbriulus variegatus & - & 974 & - & & & & & & & & & 1 & & \\
\hline Tubificidae & tutub & Tubifex tubifex & - & 14 & - & & & & & & & & & & & \\
\hline Naididae & dersp & Dero sp. & - & 1 & - & & & & & & & & & & & \\
\hline \multirow[t]{4}{*}{ Enchytraeidae } & cogla & Cognettia cf. glandulosa & - & 11 & - & & & & 11 & 1 & 30 & 66 & 12 & 73 & 62 & 57 \\
\hline & & Mesenchytraeus armatus & - & 1 & - & & & & & & & & & & & \\
\hline & & Cernosvitoviella sp. & - & 2 & - & & & & & & & & & & & \\
\hline & frisp & Fridericia ssp & - & & - & 1 & 13 & 1 & & & & & & & & \\
\hline Tricladida & & Crenobia alpina & & & 3 & & & & & & & & & & & \\
\hline Bivalvia Sphaeriidae & picas & Pisidium casertanum & $>50$ & $>50$ & & & & & & & & & & & & \\
\hline \multirow[t]{5}{*}{ Coleoptera Dytiscidae } & hymem & $\begin{array}{l}\text { Hydroporus memnonius } \\
\text { Nicolai }\end{array}$ & & & & & & & & & & & & 12 & 3 & 14 \\
\hline & hyfov & Hydroporus foveolatus Heer & $>50$ & $>50$ & & & 1 & 2 & 28 & 2 & 44 & 12 & 5 & 86 & 9 & 13 \\
\hline & hydsp & Hydroporus sp. (larvae) & & 10 & & & 34 & 1 & & 1 & & 28 & 78 & & 48 & 43 \\
\hline & agbip & Agabus bipustulatus & 26 & & & & & & 5 & 4 & & & & 1 & & 2 \\
\hline & agasp & Agabus sp. (larvae) & & & & & & & & 8 & & & & & 4 & 39 \\
\hline Hydrophilidae & helsp & Helophorus sp. & 57 & 3 & 2 & 1 & 4 & & & 2 & 2 & & 1 & 16 & 1 & \\
\hline Trichoptera Limnephilidae & limne & & $>50$ & $>50$ & 3 & 1 & & & 9 & $>100$ & $>100$ & 1 & 11 & 106 & 9 & 29 \\
\hline Heteroptera Corixidae & arcar & $\begin{array}{l}\text { Arctocorisa carinata } \\
\text { carinata }\end{array}$ & & & & & & & & & & & & 1 & 1 & 1 \\
\hline \multicolumn{17}{|l|}{ Diptera Chironomidae } \\
\hline Tanypodinae & zamel & Zavrelimyia cf. melanura & 3 & & & 3 & & & 15 & - & 3 & - & - & 69 & 2 & 5 \\
\hline \multirow[t]{4}{*}{ Diamesinae } & diame & Diamesa zernyi gr. & & & & & 22 & 71 & & - & & - & - & & & \\
\hline & & Pseudodiamesa branickii & 1 & 10 & & & & 135 & & - & & - & - & & & 9 \\
\hline & & Pseudodiamesa arctica & & 3 & & & 25 & & 1 & - & & - & - & & & \\
\hline & & Pseudokiefferiella parva & & 72 & & 4 & 9 & 4 & & - & & - & - & & & \\
\hline \multirow[t]{11}{*}{ Orthocladiinae } & ortho & Bryophaenocladius spp. & & & & & & & 3 & - & 6 & - & - & & & \\
\hline & & Corynoneura cf. scutellata & & 1 & & & & & & - & & - & - & 1 & 1 & \\
\hline & & Cricotopus sylvestris & & 5 & & & & & & - & & - & - & & & \\
\hline & & Cricotopus sylvestris gr. & $>50$ & & & & & & & - & & - & - & & & \\
\hline & & $\begin{array}{l}\text { Cricotopus / Orthocladius } \\
\text { spp. }\end{array}$ & & & & & & & & - & & - & - & 1 & & \\
\hline & & $\begin{array}{l}\text { Heterotrissocladius } \\
\text { marcidus }\end{array}$ & & 13 & & & & & 27 & - & & - & - & 2 & & 1 \\
\hline & & Limnophyes asquamatus & & & & & & 8 & & - & & - & - & & & \\
\hline & & Limnophyes spp. & & & & 3 & & & 2 & - & 6 & - & - & & & \\
\hline & & Metriocnemus ursinus & & & & 4 & & & & - & & - & - & & & \\
\hline & & Parametriocnemus stylatus & 3 & & & & 8 & 14 & & - & & - & - & & & \\
\hline & & Psectrocladius sordidellus & $>20$ & 10 & & & & & & - & & - & - & & & \\
\hline Chironominae-Tanytarsini & chiro & Paratanytarsus spp. & & & & & & & & - & & - & - & 1 & & \\
\hline \multirow[t]{3}{*}{ Chironomiinae } & & Paratanytarsus austriacus & $>50$ & $>50$ & & & & & & - & & - & - & & $3 \mathrm{Pe}$ & 3 \\
\hline & & Tanytarsus spp. & & & & & & & & - & & - & - & & & 1 \\
\hline & & Tanytarsus cf. sinuatus & & 20 & & & & & & - & & - & - & & & \\
\hline Tipulidae & & & 2 & & & & & 2 & & & & & & & & \\
\hline Empididae & & & & & & & 3 & 5 & & & & & & & & \\
\hline Ceratopogonidae & & & & & & 2 & & & & & & & & & & \\
\hline Dolichopodidae & & & & & 2 & & & & & & & & & & & \\
\hline Limoniini & & & & & & 2 & & & & & 2 & & & & & \\
\hline
\end{tabular}




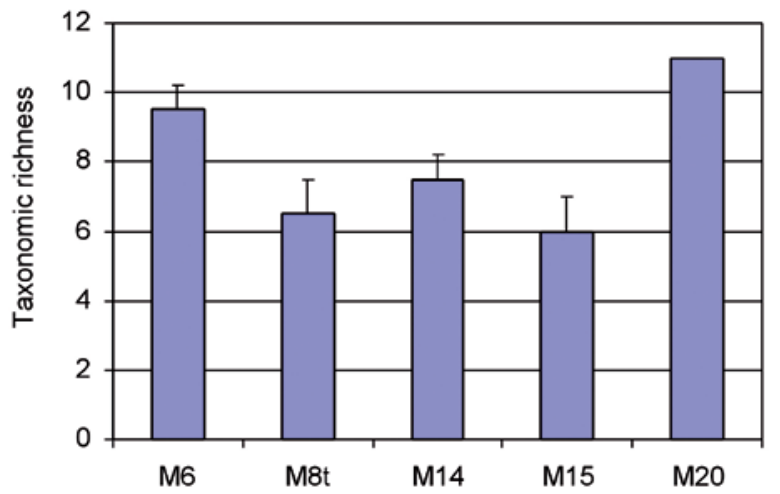

Figure 10 - Taxa richness (species level, except for Diptera and Oligochaeta to family level and Chironomidae to subfamily) between 2002 and 2007 in the five monitored ponds. Number of years sampled are two (M6, M14), three (M15, M20), or four (M8t).

note \& Sweeney 1980). Overall the data do indicate the importance of long-term monitoring for detecting changes in abiotic and biotic properties of alpine waters, especially when these changes can be rapid.

Lakes and ponds

The monitoring of fluctuations in water temperature and water level shows that these alpine ponds are quite sensitive to variation in climatic parameters such as air temperature and pluviometry. Indeed, a dry and warm aestival period leads rapidly to warmer water temperature and to a lowering in water level (and to drying of smaller ponds). This supports the idea that ponds have a low resilience and that their abiotic characteristics are highly sensitive to climatic changes.

The assessment of the macroinvertebrate assemblages and their monitoring between 2002 and 2007 showed that pond communities had a taxa richness between six and eleven taxa, values in the range of observations from other alpine ponds but particularly low compared to ponds from lower altitude (Hinden et al. 2005; Oertli et al. 2008). The composition of communities was heterogeneous between the five ponds. The particularities of each pond must be confirmed by further sampling surveys in the long-term monitoring program. Such heterogeneity is probably only partly related to the physico-chemical heterogeneity of the ponds. As already noted (Oertli et al. 2008), local variables (e.g. water chemistry, water level fluctuation) are not the only driving factors of the composition of macroinvertebrate communities in ponds of the Macun cirque. Regional factors are also involved, with colonization processes partly associated to the connectivity between ponds through tributaries. Furthermore, chance events (Jeffries 1988) constitute perhaps an important factor for the Macun ponds, where biotic influences (competition, predation) are probably low. When taking chemistry and faunistic composition together, pond M6 is distinguished from all other ponds. The only sampled non-acid pond, M6 also is characterized by high species richness. Primary productivity was not measured but the presence in summer of large beds of algal mats indicates that it is probably

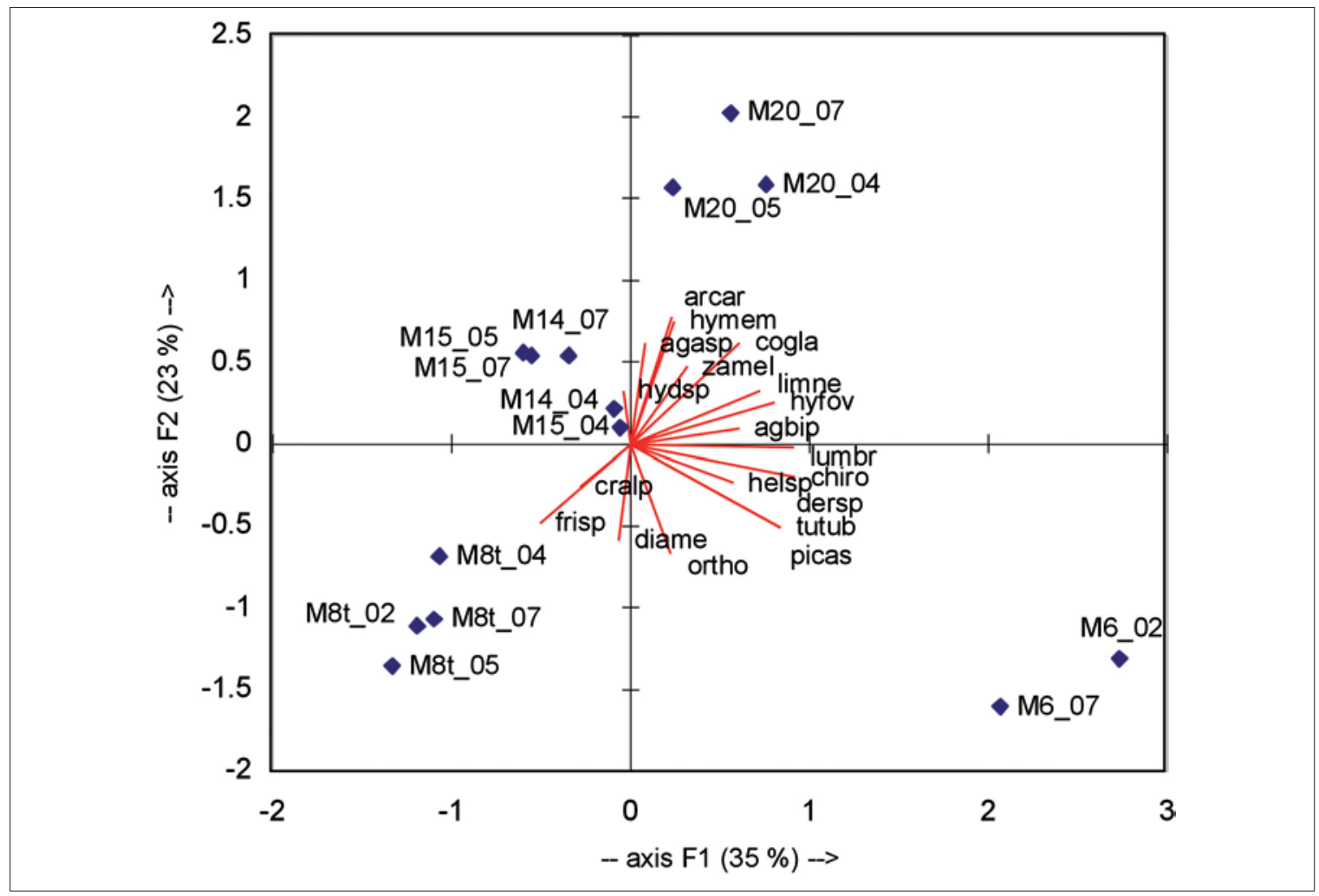

Figure 11 - Scatter plot of a principal component analysis of the macroinvertebrate assemblages (data shown in five abundance classes) of the five ponds monitored in the Macun cirque. Ponds are represented by codes followed by sample year (e.g. M8t_02 is pond M8t sampled in 2002). Taxa used in the analyses are represented by codes (see for list of taxa with respective code). 
important. Therefore M6 can be considered a glint of the future of alpine ponds with changing climate, that being a higher trophic level and also higher local richness. In the same sense the temporary pond M8t with its particular fauna is a glint of a future with lower water supply. The long-term monitoring of the ponds should provide evidence for such predictions that could already be relevant in the next 50 years.

\section{General perspective}

Monitoring can be complex and time-consuming. We have taken a parsimonious approach in this monitoring program of the Macun catchment that integrates both streams and ponds. Both avenues of assessment provide a more holistic view of ecosystem changes in the alpine landscape than by assessing either alone. Even by taking simple annual spot samples we are still showing some major shifts in the waters and biota of the catchment. The stream data has documented potential reductions in the glacial influence and perhaps a shift in water character over the short time span of the study. Similar findings have been noted by other alpine researchers of freshwaters (e.g. Brown et al. 2007). This temporal change in physico-chemistry was also seen in the invertebrate assemblages. The pond data has documented the strong spatial heterogeneity between ponds in the catchment that reflect respective differences in chemistry and degree of permanence. Both kinds of data on different kinds of water bodies provide a synergistic amount of ecological information towards a better understanding of landscape change and influence on alpine waters. As additional data are collected, the information will be used to more formally test relationships between environmental parameters and biotic measures over time.

\section{Acknowledgements}

Numerous people have assisted in the field over the course of the study: M. Hieber, V. Wenzelides, J. Ruegg, J. Logue, L. Shama, C. Baumgartner, S. Matthaei, S. Blaser, K. Barnard, C. Jolidon, K. Gafner, D. Tonolla, B. Imhof, M. Zbinden, R. Vukelic, S. Mannes, A. Fijarczyk and T. Buser for streams, and N. Indermuehle, N. Menetrey, L. Sager, Z. Fleury, M. Massa, A. Stoll, E. Lecomte, and J. O'Rourke for the ponds. We thank R. Illi for completing all the chemical analyses of water samples. We greatly appreciate the logistical support from the Swiss National Park, in particular F. Filli, N. Willy, T. Scheurer and R. Haller (especially for the map), and the local communities of Lavin and Zernez for their interest in the project. This work was partly supported by the Research Committee from the Swiss National Park. Help in identification was provided by Gilles Carron (Coleoptera), Brigitte Lods-Crozet (Chironomidae), Narcisse Giani (Oligochaeta), Verena Lubini (Trichoptera) and Nigel Thew (Sphaeriidae).

\section{References}

Brown, L.E., D.M. Hannah \& A.M. Milner 2007. Vulnerability of alpine stream biodiversity to shrinking glaciers and snowpacks. Global Change Biology 131: 958-966.

Brown, L.E., A.M. Milner \& D.M. Hannah 2006. Stability and persistence of alpine stream macroinvertebrate communities and the role of physicochemical habitat variables. Hydrobiologia 560: 159-173.

Donath, U. \& C.T. Robinson 2001. Ecological characteristics of lake outlets in Alpine environments of the Swiss Alps. Archiv für Hydrobiologie 150: 207-225.

Jeffries, M. 1988. Measuring talling element of chance in pond populations. Freshwater Biology 20: 383-393.

Hieber, M., C.T. Robinson, U. Uehlinger \& J.V. Ward 2005. A comparison of benthic macroinvertebrate assemblages among different types of alpine streams. Freshwater Biology 50: 2087-2100.

Hinden, H. 2004. La biodiversité des petits plans d'eau alpins de Suisse. Travail de Diplôme. Université de Genève, Genève.

Hinden, H., B. Oertli, N. Menetrey, L. Sager \& J.B. Lachavanne 2005. Alpine pond biodiversity: what are the related environmental variables? Aquatic Conservation: Marine and Freshwater Ecosystems 15: 613-624.

Ilg, C. \& E. Castella 2006. Patterns of macroinvertebrate traits along three glacial stream continuums. Freshwater Biology 51: 840-853.

Indermuehle, N \& B. Oertli 2007. Mise en place d'un monitoring de la biodiversité des étangs du cirque de Macun (Parc National Suisse): les macroinvertébrés. Nationalpark-Forschung in der Schweiz 94: 173-182.

Körner, C. 1999. Alpine plant life. Berlin.

Lecomte, E. 2008. Typologie des étangs temporaires de Macun: Parc National Suisse, Grisons. Travail de Diplôme. Ecole d'ingénieurs de Lullier, Genève.

Lods-Crozet, B., E. Castella, D. Cambin, C. Ilg, S. Knispel \& H. Mayor-Simeant 2001. Macroinvertebrate community structure in relation to environmental variables in a Swiss glacial stream. Freshwater Biology 46: 1641-1661.

Maiolini, B., V. Lencioni, A. Boggero, B. Thaler, A.F. Lotter \& B. Rossaro 2006. Zoobenthic communities of inlets and outlets of high altitude Alpine lakes. $\mathrm{Hy}$ drobiologia 562: 217-229.

Malard, F., K. Tockner \& J.V. Ward 2000. Physicochemical heterogeneity in a glacial riverscape. Landscape Ecology 15: 679-695.

Monaghan, M.T., C.T. Robinson, P. Spaak \& J.V. Ward 2005. Macroinvertebrate diversity in fragmented Alpine streams: implications for freshwater conservation. Aquatic Sciences - Research Across Boundaries 67,4: 454-464. Oertli, B., D. Auderset Joye, E. Castella, R. Juge, A. Lehmann \& J.B. Lachavanne 2005. PLOCH: a standardised method for sampling and assessing the biodiversity in ponds. Aquatic Conservation: Marine and Freshwater Ecosystems 15: 665-679. 
Oertli, B, N. Indermuehle, S. Angélibert, H. Hinden \& A. Stoll 2008. Macroinvertebrate assemblages in 25 high alpine ponds of the Swiss National Park (Cirque of Macun) and relation to environmental variables. Hydrobiologia 597: 29-41.

Robinson, C.T., M. Hieber, V. Wenzelides \& B. LodsCrozet 2007. Macroinvertebrate assemblages of a high elevation stream/lake network with an emphasis on the Chironomidae. Archiv für Hydrobiologie 169: 25-36.

Robinson, C.T. \& S. Matthaei 2007. Hydrological heterogeneity of an Alpine stream/lake network in Switzerland. Hydrological Processes 21: 3146-3154.

Rosset, V., B. Oertli, S. Angélibert \& N. Indermuehle 2008. The local diversity of macroinvertebrates in alpine ponds as an indicator of global change: a gastropod case-study. Verhandlungen Internationaler Verein Limnologie 30: 482-484.

Stoll, A. 2005. La diversité biologique des petits plans d'eau de Macun (Parc National). Travail de Diplôme. Ecole d'ingénieurs de Lullier, Genève.

Vannote, R.L. \& B.W. Sweeney 1980. Geographical analysis of thermal equilibria: a conceptual model for evaluating the effect of natural and modified thermal regimes on aquatic insect communities. American Naturalist 115: 667-695.

\section{Authors}

Christopher T. Robinson

Christopher T. Robinson is a senior research scientist with the Department of Aquatic Ecology, Eawag, and a lecturer at the ETH Zürich. His primary interest is the ecology of alpine waters with an emphasis on streams. He has been a member of the Research Commission for the Swiss National Park since 1998.

Department of Aquatic Ecology, Eawag, 8600 Duebendorf, Switzerland and Institute of Integrative Biology, ETH, Zürich, Switzerland.

\section{Beat Oertli}

Beat Oertli is Professor at the University of Applied Sciences of Western Switzerland, and coordinates the research group "Biodiversity conservation". His activities are focused on the biodiversity of ponds (macroinvertebrates, macrophytes, amphibians): assessment methods, relation to environmental variables (local and regional), and impact of perturbations (e.g. nutrient enrichment, climate warming). 